\title{
A review of the nutritional and health aspects of goat milk in cases of intestinal resection
}

\author{
Inmaculada LóPez-Aliaga*, Javier Díaz-Castro, Ma José M. Alférez, \\ Mercedes Barrionuevo, Margarita S. CAmpos \\ Department of Physiology and Institute of Nutrition and Food Technology "José Mataix", \\ University of Granada, E-18071 Granada, Spain
}

Received 22 January 2010 - Revised 13 April 2010 - Accepted 14 April 2010

Published online 8 July 2010

\begin{abstract}
The objective of this paper is to review the beneficial effects of the dietary inclusion of goat milk on the utilization of protein, fat and minerals ( $\mathrm{Ca}, \mathrm{P}, \mathrm{Mg}, \mathrm{Fe}, \mathrm{Cu}, \mathrm{Zn}$ and $\mathrm{Se}$ ), which affect malabsorption syndrome caused by resection of the intestine. The consumption of a goat milkbased diet, compared to bovine milk, has shown a higher protein efficiency ratio, protein digestibility, nitrogen balance and food conversion ratio in rats with resection of the distal small intestine. Goat milk diet also improves digestive utilization of fat, reduces fecal losses and decreases plasma triglycerides. Goat milk diet increases the biliary secretion of cholesterol and causes a decrease in plasma cholesterol levels, whereas the levels of bile phospholipids, biliary acid and lithogenic index remain normal. In relation to mineral bioavailability, apparent digestibility coefficients and the balance of calcium, phosphorus, magnesium, iron, copper and zinc are higher after the consumption of a goat milk diet compared to bovine milk diet in resected rats, despite the intestinal absorptive surface being reduced by $50 \%$ due to intestinal resection. Based on the particular biological, nutritional and metabolic characteristics, these reports suggest that goat milk can be an excellent natural food in cases of malabsorption syndrome, as an alternative to bovine milk.
\end{abstract}

goat milk / protein / fat / minerals / intestinal resection

\begin{abstract}
摘要 - 羊奶对肠切除病人的营养和健康作用 - 综述。本文论述了羊奶中的蛋白、脂肪和矿 物元素 $(\mathrm{Ca} 、 \mathrm{P} 、 \mathrm{Mg} 、 \mathrm{Fe} 、 \mathrm{Cu} 、 \mathrm{Zn}$ 和 $\mathrm{Se})$ 对由于肠切除引起营养不良病人的营养和健康 作用。在小肠末梢切除的小鼠模型中，羊奶食物比牛奶具有较高的蛋白效率比、蛋白消化 性、氮平衡和食物转化率。羊奶同样也能提高脂肪的消化利用率, 减少排泄量以及降低血 浆三酸甘油酯浓度。羊奶食物可以增加胆固醇的分泌和引起血浆胆固醇水平的降低, 而磷 脂、胆酸和胆汁成石指数保持正常。关于矿物质的生物利用率, 在实验小鼠中, 尽管小鼠 肠道被切除, 肠吸收性降低了 $50 \%$, 但是羊奶食物表观消化系数和钲、磷、镁、铁、铜及 锌平衡均比牛奶高。基于特殊的生物学、营养和代谢特性, 本文认为对由于肠道切除导致 的吸收综合症病人，羊奶可以替代牛奶是一种极好的营养食品。
\end{abstract}

\section{羊奶 / 蛋白 / 脂肪 / 矿物元素 / 肠切除}

Résumé - Une revue sur les aspects nutritionnels et santé du lait de chèvre dans le cas de résections intestinales. L'objectif de cet article est de passer en revue les effets bénéfiques de

*Corresponding author (通讯作者): milopez@ugr.es 
l'inclusion du lait de chèvre dans l'alimentation sur l'utilisation des protéines, des matières grasses et des minéraux ( $\mathrm{Ca}, \mathrm{P}, \mathrm{Mg}, \mathrm{Cu}, \mathrm{Zn}$ et Se) dans le contexte du syndrome de malabsorption causé par la résection de l'intestin. La consommation d'un régime basé sur du lait de chèvre a montré un ratio d'efficacité protéique, une digestibilité des protéines, une balance azotée et un ratio de conversion alimentaire plus élevés chez les rats ayant subi une résection de la partie distale de l'intestin grêle, en comparaison au régime à base de lait de vache. Le régime à base de lait de chèvre améliore aussi l'utilisation digestive des matières grasses, réduit les pertes fécales et diminue les triglycérides dans le plasma. Le régime à base de lait de chèvre augmente la sécrétion biliaire du cholestérol et provoque une diminution des niveaux de cholestérol du plasma, alors que les niveaux de phospholipides de la bile, de l'acide biliaire et l'indice lithogénique restent normaux. En relation avec la biodisponibilité des minéraux, les coefficients de digestibilité apparente et les équilibres en calcium, phosphore, magnésium, fer, cuivre et zinc sont plus élevés après la consommation du régime à base de lait de chèvre en comparaison à celui à base de lait de vache chez les rats résectionnés, malgré une surface intestinale absorbante réduite de $50 \%$ en raison de la résection intestinale. Sur la base des caractéristiques biologiques, nutritionnelles et métaboliques, ces études suggèrent que le lait de chèvre peut être un excellent aliment naturel dans les cas du syndrome de malabsorption, en alternative au lait bovin.

\section{lait de chèvre / protéine / matière grasse / minéraux / résection intestinale}

\section{INTRODUCTION}

Small intestinal resection is highly topical, and this methodology is currently being used to treat certain illnesses and nutritional disorders, as well as patients who have suffered accidents that have led to the extirpation of part of the intestine. The practice of small intestinal resection has led to significant advances in our understanding of digestive physiology and capacity of the body to adapt to nutritional deficiency. Nevertheless, consequences of this surgical intervention may influence its therapeutic value.

Various studies have been conducted on small intestine resection and its effects on digestive and metabolic functions. Resection of the distal small intestine leads to a complicated pathological situation in which the organism is confronted with the malabsorption of protein $[9,47]$, fat $[6,19,20]$ and divalent cations (such as calcium, magnesium, iron, copper, zinc and selenium) $[2,3,30$, $31,46]$. Intestinal resection can affect the rate of nutrient absorption by reducing the surface area available for nutrient transport and speeding up the transit time of food through the intestine, thus limiting the time nutrients are in contact with the absorptive surface. Many investigators have confirmed the development of anatomical and functional adaptations in the remaining segment through increases in villus height and in crypt depth $[25,32,38,66]$.

The capacity of this compensatory response is dependent on factors such as the site of resection, the amount of bowel removed, the time elapsed after surgery and the type of nutrition provided. Nevertheless, from a nutritional standpoint, the only manageable factor in human beings continues to be dietary composition [21].

Advances in food technology, among a society increasingly concerned about health issues and quality of life, have led nutritional science to search for new foods that offer added value and health benefits, and help delay or even prevent the occurrence of certain diseases. In this context, goat milk has been studied as a natural food with excellent nutritional properties. Although the consumption of goat milk and its products is currently low, its acceptance is rising with the current trend in favor of high quality, nutritious and healthy foods [17].

The importance of goat milk as a food resides in its high digestibility and nutritional value, as well as its therapeutic and dietary characteristics [29, 50, 59]. Goat milk is an excellent source of high quality 
protein and easily absorbed [12, 55] and more digestible than cow milk due to smaller fat globule size and higher contents of short- and medium-chain fatty acids [56].

The smaller-sized fat globules provide a better dispersion and a more homogeneous mixture of fat in the milk, and their larger surface area enhances further pancreatic lipase activity, making goat milk easier to digest $[13,17,34,58]$. Goat milk has a high proportion of short- and medium-chain saturated fatty acids, such as butyric (C4:0), caproic (C6:0), caprylic (C8:0) and capric (C10:0), and long-chain mono- and polyunsaturated fatty acids [56].

The fat sources of medium-chain triglycerides (MCT) may be advantageous under certain circumstances since they are absorbed intact and do not undergo degradation and reesterification processes. MCT are more readily hydrolyzed by pancreatic enzymes than is long-chain triglyceride fat. Micelle formation is not required for absorption, since the molecules are taken up directly into the portal vein. The fatty acids within MCT penetrate the mitochondria of hepatic cells, independently of carnitine acyl-CoA transferase $[49,64]$. Thus they contribute to easier, faster digestion, a feature which makes them especially suitable for post-resection feeding. Finally, these MCT fatty acids are oxidized to produce a rapid energy discharge that can be used in various metabolic processes and produce lower deposits of fat within the organism [56].

Noteworthy minerals include calcium and phosphorus, which feature high digestibility levels, partly because they are associated with milk casein and also are present in optimum proportions for absorption (Ca:P 1.0:1.5). Goat milk supplies adequate amounts of vitamin A, thiamine, riboflavin and pantothenic acid. The only negative aspect of the composition of goat milk concerns its low content of folic acid [11, 36, 57] and vitamin $B_{12}[35,57,63]$.

Goat milk, taking into account its nutrient content, constitutes an alternative to cow milk that is highly beneficial in certain aspects of human nutrition, especially for children. Many of the adverse reactions that may be produced by consuming cow milk, and especially those concerning certain protein fractions, as well as lactose intolerance, can often be avoided by substituting it with goat milk $[54,56]$.

\section{EFFECTS OF THE CONSUMPTION OF GOAT MILK ON THE NUTRITIVE UTILIZATION OF PROTEIN}

In light of utilization of goat milk protein, the fecal excretion of nitrogen tends to increase after small intestinal resection, resulting in a marked decrease in protein absorption [7, 9]. However, this reduction is moderate in the case of proximal resection, while aggravated if the resection is done in distal.

Resected animals tend to recover gradually, but this is hardly noticeable at 6 and 9 weeks after resection. Nevertheless, the recovery is apparent after 3 months although it is not total, and the recovery rate is greater in cases of $50 \%$ resection than in those of $80 \%$ resection [9].

The removal of the ileum and part of the jejunum interferes with the nutritional utilization of protein. When $50 \%$ of the distal small intestine is removed there is a deterioration in the digestive utilization of protein [9] which improves in time (6 months postsurgery). At 6 months after resection, there is an evident recovery in this respect, and total recovery of the metabolic utilization of protein, which is maintained in the long term (1 year) [7].

A qualitative change in the dietary fat source, from $100 \%$ olive oil to equal parts of MCT, sunflower seed oil and olive oil together with the vitamin $\mathrm{D}_{3}$ supplement, accelerates the recovery of the digestive utilization of protein in intestinally resected rats [48]. 
López-Aliaga et al. [43] investigated the effect of dietary goat milk on the nutritive utilization of protein in rats with resection of $50 \%$ of the distal small intestine. They reported that goat milk consumption led to a better protein efficiency ratio and food conversion efficiency together with a higher digestibility of protein and high values of nitrogen balance values in comparison with cow milk, particularly in rats with distal small intestine resection.

The proteins in goat milk are digested readily and their constituent amino acids are absorbed efficiently [12, 55]. With respect to the parameters related to protein metabolism, the goat milk diet compared to cow milk produced the highest serum levels of total protein, whereas the urea serum levels were within the range of normality.

Goat milk contains the same types of casein, such as alpha, beta, kappa caseins, beta-lactoglobulin and alpha-lactalbumin, although the levels are different. However, there are structural and immunological differences compared to cow's milk. Caseins constitute the greater protein fraction of goat milk although cow milk has higher casein content than goat milk. With regard to caseins, goat milk is richer in beta-casein and poorer in alpha-s1 casein, whereas in the cow's milk alpha-s1 casein is the most abundant [17, 56, 61]. Goat milk contains relatively higher levels of alpha-s2 casein in comparison with cow's, although the sum alpha-s1 casein plus alpha-s2 casein in goat milk is lower than in the alpha-s1 casein of cow's [17]. The most abundant serum proteins in goat milk are alphalactalbumin and beta-lactoglobulin.

\section{EFFECTS OF DIETARY GOAT MILK ON THE NUTRITIVE UTILIZATION OF FAT}

The most striking problem arising after resection of the distal small intestine is the increase in the excretion of fat $[6,19,20]$.
The resection of $50 \%$ of the distal small intestine produces a significant decrease in the amount of fat $[6,19,20]$ due to a diminution in the absorptive surface area and to the greater intestinal transit speed, suggesting there is less contact time between the fat and the mucosa. Moreover, ileal resection creates a severe interruption in enterohepatic circulation, which gives rise to a notable decrease in the production of biliary salts [53], despite increased synthesis of the latter [63], which impedes the absorption of fats [22].

The influence of diets containing different types of fat (olive oil or a mixture of 1/3 MCT, 1/3 sunflower seed oil and 1/3 olive oil), and the effect of ursodeoxycholic acid, an exogenous bile acid, on the nutritive utilization of fat has also been studied in rats with intestinal resection. The results showed that the modification of dietary lipid quality improves the digestive utilization of fat and that this improvement is maintained when ursodeoxycholic acid is added to the diet. Moreover, the fatty acid profile in serum revealed no deficit in essential fatty acids caused by intestinal resection or by type of diet, but did clearly reflect the source of dietary fat [19].

Alférez et al. [1] studied the effects of goat and cow milk fat on the digestive utilization and on some of the biochemical parameters related to the metabolism of lipids, in malabsorption syndrome. The consumption of a goat milk-based diet for 14 days improves digestive utilization of fat (Tab. I) and reduces fecal losses, in comparison to cow milk, and it approaches the values obtained for olive oil. The fat of goat milk is more digestible than that of cow milk because the fat globules of goat milk are smaller and present a greater surface area; in consequence, lipases in the gut are able to attack the lipids more rapidly $[34,36,56]$.

In an Algerian study of infants with malabsorption syndromes, the substitution of cow milk with goat milk caused higher rates of intestinal fat absorption [26]. 
Table I. Comparison of goat and cow milk based diet for protein, fat and mineral absorption in rats with resection of distal small intestine.

\begin{tabular}{|c|c|c|c|}
\hline & Goat milk diet & Cow milk diet & References \\
\hline Protein & & & [43] \\
\hline ADC (\%) & $95.19 \pm 0.36$ & $92.44 \pm 0.20$ & \\
\hline Balance $\left(\mathrm{mg} \cdot\right.$ day $\left.^{-1}\right)$ & $204.86 \pm 13.33$ & $180.35 \pm 11.94$ & \\
\hline Fat & & & {$[1]$} \\
\hline ADC (\%) & $86.8 \pm 1.2$ & $73.2 \pm 1.2$ & \\
\hline TG levels $\left(g \cdot \mathrm{L}^{-1}\right)$ & $0.81 \pm 0.021$ & $0.82 \pm 0.015$ & \\
\hline Cholesterol $\left(\mathrm{g} \cdot \mathrm{L}^{-1}\right)$ & $0.61 \pm 0.017$ & $0.75 \pm 0.016$ & \\
\hline Calcium & & & [15] \\
\hline $\mathrm{ADC}(\%)$ & $34.1 \pm 1.6$ & $25.9 \pm 1.0$ & \\
\hline Balance $\left(\mathrm{mg} \cdot \mathrm{day}^{-1}\right)$ & $28.7 \pm 1.3$ & $25.7 \pm 1.4$ & \\
\hline Phosphorus & & & [15] \\
\hline $\mathrm{ADC}(\%)$ & $62.4 \pm 1.4$ & $50.6 \pm 1.6$ & \\
\hline Balance $\left(\mathrm{mg} \cdot \mathrm{day}^{-1}\right)$ & $20.0 \pm 1.8$ & $12.9 \pm 1.6$ & \\
\hline Magnesium & & & [43] \\
\hline $\mathrm{ADC}(\%)$ & $70.42 \pm 2.84$ & $53.32 \pm 1.74$ & \\
\hline Balance $\left(\mathrm{mg} \cdot\right.$ day $\left.^{-1}\right)$ & $3.49 \pm 0.21$ & $2.98 \pm 0.35$ & \\
\hline Iron & & & {$[5]$} \\
\hline $\mathrm{ADC}(\%)$ & $16.1 \pm 1.2$ & $9.2 \pm 0.7$ & \\
\hline Balance $\left(\mu \mathrm{g} \cdot\right.$ day $\left.^{-1}\right)$ & $73.6 \pm 5.5$ & $47.4 \pm 3.5$ & \\
\hline Copper & & & {$[5]$} \\
\hline $\mathrm{ADC}(\%)$ & $43.6 \pm 2.0$ & $21.9 \pm 1.6$ & \\
\hline Balance $\left(\mu\right.$ g.day $\left.^{-1}\right)$ & $33.3 \pm 2.0$ & $20.8 \pm 2.4$ & \\
\hline Zinc & & & [2] \\
\hline $\mathrm{ADC}(\%)$ & $33.6 \pm 2.6$ & $14.4 \pm 0.8$ & \\
\hline Balance $\left(\mu \mathrm{g} \cdot\right.$ day $\left.^{-1}\right)$ & $169.4 \pm 10.4$ & $91.3 \pm 5.6$ & \\
\hline Selenium & & & [2] \\
\hline ADC (\%) & $92.88 \pm 0.29$ & $87.38 \pm 0.58$ & \\
\hline Balance $\left(\mu \mathrm{g} \cdot\right.$ day $\left.^{-1}\right)$ & $1.1 \pm 0.03$ & $0.99 \pm 0.04$ & \\
\hline
\end{tabular}

ADC: apparent digestibility coefficient, TG: triglycerides.

Moreover, a goat milk-based diet decreases the plasma triglyceride concentration, whereby a positive effect occurred on the lipid metabolism similar to that of olive oil. Goat milk also decreases plasma LDLcholesterol levels in rats. This effect is partly due to the higher levels of MCT in goat's milk (34\%) than in cow milk $(21 \%)$, as the presence of MCT in the diet reduces the synthesis of endogenous cholesterol and its intestinal absorption [23]. Furthermore, goat milk fat has a higher monounsaturated fatty acid content than does cow milk [28], and these fatty acids are known to have a hypocholesterolemic effect $[37,56]$. The levels of HDL-cholesterol, glutamate oxalacetate 
transaminase and of glutamate piruvate transaminase have been found to be within the normal limits described in the bibliography for the rat [45].

\section{EFFECTS OF DIETARY GOAT MILK ON CERTAIN ASPECTS OF BILIARY PHYSIOLOGY}

Studies in rats have shown that the resection of the distal small intestine modifies biliary physiology $[24,41]$. The removal of $50 \%$ of the distal small intestine raises the novo hepatic synthesis of bile acids, while the addition of ursodeoxycholic acid decreases bile flow and the osmotic activity of bile acid in resected rats and the bile acidindependent bile flow increase.

In these studies of resected rats [24, 41], there was a decrease in the biliary secretion of cholesterol and phospholipids, and the lithogenic index fell, with respect to the control group. Resected rats fed equal parts of MCT, olive oil and sunflower seed oil as the fat source for 1 or 3 months showed increases in the biliary secretion of cholesterol and phospholipids, and in the lithogenic index, in comparison with resected rats fed olive oil as the fat source. The addition of ursodeoxycholic acid to the diet led to the decoupling of bile acid and bile lipid secretion [41].

The influence of goat and cow milk in the diet on several aspects of biliary physiology has been studied by López-Aliaga et al. [45], who reported that goat milk consumption, compared with that of cow milk, increased the biliary secretion and provoked a reduction in plasma cholesterol concentration, meanwhile bile phospholipids, biliary acid concentration and the lithogenic index remained unchanged.

Moreover, consumption of this type of milk decreases the plasma concentration of triglycerides and therefore has a positive effect, similar to that of virgin olive oil, on the lipid metabolism; hence, it may be recommended for consumption by the general consumer [45].

\section{EFFECTS OF THE CONSUMPTION OF GOAT MILK ON MINERAL BIOAVAILABILITY}

Resection of the small intestine has important nutritional consequences for mineral homeostasis [39], in reducing mineral absorption and thus provoking malnutrition and nutritional deficiencies.

\subsection{Calcium and phosphorus}

Distal resection of the small intestine provokes adverse effects on the homeostasis of calcium and phosphorus. Calcium malabsorption is common in patients who have undergone massive resection of the small intestine [33]. Factors contributing to the decrease in calcium absorption in these patients include the malabsorption of dietary vitamin $\mathrm{D}$ and 25 -hydroxyvitamin $\mathrm{D}$ as a result of the interruption of enterohepatic circulation and an increase in fat excretion. When $50 \%$ of the distal small intestine is removed in rats, the resulting impairment in calcium absorption becomes a serious nutritional problem $[14,16]$.

Other studies by Barrionuevo et al. [8] have demonstrated that the loss of the ileum and part of the jejunum impairs the nutritive utilization of phosphorus. The resultant defect in fat absorption is accompanied by a reduced digestive utilization of vitamin D and a decline in bile acid absorption, causing a greater loss of endogenously synthesized vitamin D [18] and hence insufficient calcium and phosphorus absorption.

One of the main reasons why milk is considered a food of exceptional quality is due to the minerals it provides, and especially of calcium and phosphorus in optimum proportions for absorption (Ca:P 1.0:1.5). As remarked by Moreno [52], 
the consumption of a suitable quantity of $\mathrm{Ca}$, in proportion to that of $\mathrm{P}$, would be difficult without the inclusion in the diet of a considerable amount of milk or milk-based products. Moreover, goat milk has a high proportion of MCT [27, 36, 56], a factor that is important in the nutritive utilization of calcium and phosphorus [3, 44].

López-Aliaga et al. [42] found that the digestive utilization of calcium and the calcium content in the femur, sternum and the longissimus dorsi muscle is greater in control rats fed a goat milk-based diet than among rats given a cow milk diet, and concluded that goat milk has a beneficial effect on the metabolism of calcium, a fact that is of great importance in the metabolic function within the bones.

Taking these considerations into account, Campos et al. [15] evaluated the effects of a goat milk-based diet, in comparison with cow milk counterpart, on the nutritive utilization of calcium and phosphorus in rats with resection of $50 \%$ of the distal small intestine. This study showed that the apparent digestibility coefficient of calcium and phosphorus is higher among rats given goat milk, despite the fact that the absorptive surface was reduced by $50 \%$ (Tab. I). Serum calcium and phosphorus levels and ionic calcium were higher with the goat milk, whereas the parathyroid hormone levels were lower. Calcium content in the preferential target organs (femur, sternum and the longissimus dorsi muscle) was higher in the rats given the goat milk diet. The goat milk diet had a positive effect on the deposit of phosphorus in the organs where the high consumption of ATP requires its presence (i.e. the muscle, brain, kidney and spleen); these effects were observed even after $50 \%$ of the small intestine had been removed.

\subsection{Magnesium}

A previous study by López-Aliaga et al. [46] showed that intestinal resection $(50 \%$ of the distal small intestine) reduced the digestive utilization of magnesium as reflected in the mineral content of bone; however, the digestive and metabolic utilization of magnesium were observed to recover by 3 months post-surgery.

The effect of the type of dietary fat and cholecalciferol on magnesium absorption in rats with resection of $50 \%$ of the distal small intestine was studied by Lisbona et al. [40], who found that the capacity of magnesium absorption in the proximal colon increases markedly in rats with resection of $50 \%$ of the distal small intestine fed a diet supplemented with cholecalciferol and mixtures of equal parts of MCT, sunflower oil and olive oil as the source of dietary fat. These results reflect the clinical significance of the diet supplied in mitigating micronutrient malabsorption syndromes.

López-Aliaga et al. [43] reported that the magnesium apparent digestibility coefficient was greater when goat milk was included in the diet of rats with resection of the distal small intestine, this effect being reflected in the greater quantity of this mineral stored in bone (femur and sternum). With respect to the levels of magnesium in the blood, the animals given the goat milk diet presented a higher quantity of magnesium in the erythrocytes, due to its greater digestive utilization.

\subsection{Iron and copper}

After resection of $50 \%$ of the distal small intestine, there is a reduction in the digestive use of iron (40\%) and copper (16\%) [5]. The effect of dietary supplementation with ascorbic acid or cholecalciferol on iron utilization was studied by Hartiti et al. [30], using the metabolic balance technique in rats with intestinal resection. The addition of ascorbic acid or cholecalciferol to the diet increased the digestive utilization and retention of iron in both transected and resected rats and reduced the concentration of iron in muscle.

The influence of goat and cow milk on the nutritive utilization of iron was studied 
by López-Aliaga et al. [42]. The apparent digestibility coefficient, balance and iron content in the reserve organs (liver and sternum) were found to be greater in control rats fed the goat milk-based diet in comparison with the cow milk diet. The conclusion drawn from these experiments is that goat milk has a beneficial effect on the metabolism of calcium and iron, which minimizes any interaction between the two minerals.

Park et al. [57] investigated bioavailabilities of iron from dehydrated whole and skim goat milk in iron-deficient rats. Hemoglobin regeneration efficiency was higher for group fed whole goat milk than for that fed skim goat milk, and higher for goat than for cow milk and concluded that iron bioavailability of goat milk is superior to cow milk when fed to anemic rats.

Barrionuevo et al. [5] reported that the resected animals fed with a goat milk-based diet presented a higher level of iron digestibility and balance than those given a cow milk-based diet. In animals with resection of the distal small intestine, iron content in the liver (the preferential reserve organ for iron in the form of ferritin), spleen (and organ that contains a lower proportion of iron, in the form of hemosiderin) and sternum (a notable erythropoietic organ) is higher with the goat milk diet than with the cow milk diet.

The effects of the dietary inclusion of freeze-dried goat and cow milk on the bioavailability of copper were studied in control rats [10] and in rats with malabsorption syndrome [5]. The apparent digestibility coefficient and balance of copper were higher in both the control and the resected animals given the goat milk than among those given cow milk. The copper content in the kidney and in the femur was greater when the animals consumed the goat milk-based diet. This study shows that kidney is the organ that best reflects events at the digestive and metabolic levels concerning copper metabolism.

\subsection{Zinc and selenium}

Alterations in zinc absorption mechanisms after intestinal resection in rats have been described by several authors [4, 62]. Hartiti et al. [31] showed a significant decrease in the digestive and metabolic utilization of zinc at one month after distal small resection. When the diet was supplemented with cholecalciferol, the nutritive utilization of zinc increased. This positive effect was attributed to an increase in the concentration of zinc-binding protein in the small intestine of the rat. The addition of ascorbic acid also enhanced the nutritive utilization of zinc, although to a lesser degree than did cholecalciferol.

In order to determine the post-absorptive effect of intestinal resection, Hartiti et al. [31] measured the distribution of zinc in the organism and observed that, despite the marked decline in the nutritive utilization of zinc, the distribution of the element in the organism was not altered by resection. Zinc content in the liver, femur, sternum, testes and longissimus dorsi muscle was not influenced by resection, remaining within physiological limits.

Alférez et al. [2] studied the effects of the dietary inclusion of freeze-dried goat and cow milk on the bioavailability of zinc and selenium in transected and resected rats, and concluded that the consumption of the goat milk diet produced a greater bioavailability of zinc and selenium and a greater deposit of zinc in key organs, with respect to the cow milk diet. The bioavailability of zinc and selenium in goat milk is higher than in cow milk, due to the greater amount of vitamins $\mathrm{C}$ and $\mathrm{D}[34,60]$. According to Hartiti et al. [31], this could contribute to the greater digestive utilization of zinc in animals fed a goat milk diet. Furthermore, goat milk is richer in cysteine, an amino acid active in the absorption and metabolism of zinc and selenium. Moreover, medium-chain fatty acids, which are absorbed 
within the intestinal cells without re-esterification and which directly enter the portal circulation, would probably favor intestinal adaptation, owing to the increased quantity of other nutrients transported through the basolateral membrane of the enterocyte. Therefore, energy retention was favored in a direct way by the high content of MCT in goat milk, besides this beneficial effect on metabolism could be a consequence of the greater absorption of other micronutrients such as zinc and selenium.

\section{VITAMINS IN GOAT MILK}

Goat milk is also a good source of vitamins such as A, D, E, thiamine, riboflavin and niacin. Goat's milk has low levels of folate $[11,36,56,58]$. Several authors $[36,56,58,65]$ reported that goat milk is lower in vitamin $B_{12}$, vitamin $A$, vitamin $C$ and vitamin $\mathrm{D}$ than cow's milk. In contrast McCance and Widdowson [59] report equal amounts of vitamin $\mathrm{C}$ in both goat and cow milk and lower amounts of vitamins A and $\mathrm{D}$ in goat milk.

\section{CONCLUSIONS}

In conclusion, the dietary inclusion of goat milk for the intestinal resected animals improves the nutritional utilization of protein with a higher protein efficiency ratio, protein digestibility, nitrogen balance and food conversion ratio. Likewise, it has a positive effect on the lipid metabolism by reducing fat fecal losses and causing a decrease in plasma triglyceride and LDLcholesterol concentrations. Moreover, goat milk consumption leads to a higher nutritional utilization of minerals, such as $\mathrm{Ca}$, $\mathrm{P}, \mathrm{Mg}, \mathrm{Fe}, \mathrm{Cu}$ and $\mathrm{Zn}$. This suggests that goat milk could be an excellent food in cases of malabsorption syndrome in order to overcome or palliate, at least in part, the negative effects of intestinal resection on the nutritive utilization of macro- and micronutrients in humans as in rodent experimental animals.

Goat milk therefore can be used as a good alternative to cow milk, and its inclusion in the habitual diet could be highly beneficial to humans afflicted with malabsorption syndrome due to surgery.

Acknowledgment: Thanks go to Dr. George Haenlein for the dedication and for the interest in publishing this paper.

\section{REFERENCES}

[1] Alférez M.J.M., Barrionuevo M., LópezAliaga I., Sanz-Sampelayo M.R., Lisbona F., Campos M.S., The digestive utilization of goat and cow milk fat in malabsorption syndrome, J. Dairy Res. 68 (2001) 451-461.

[2] Alférez M.J.M., López-Aliaga I., Barrionuevo M., Campos M.S., Effect of dietary inclusion of goat milk on the bioavailability of zinc and selenium in rats, J. Dairy Res. 70 (2003) 181-187

[3] Alférez M.J.M., López-Aliaga I., Barrionuevo M., Lisbona F., Hartiti S., Pallarés I., Campos M.S., Calcium absorption in rats with distal intestinal resection: influence of type of dietary fat, cholecalciferol and nature of the adaptative response, Int. J. Vitam. Nutr. Res. 66 (1996) 59-65.

[4] Antonson D.L., Vanderhoof J.A., Zinc absorption following massive small-bowel resection in the rat, Dig. Dis. Sci. 27 (1982) 789-793.

[5] Barrionuevo M., Alférez M.J.M., LópezAliaga I., Sanz Sampelayo M.R., Campos M.S., Beneficial effect of goat milk on nutritive utilization of iron and copper in malabsorption syndrome, J. Dairy Sci. 85 (2002) 657-664.

[6] Barrionuevo M., Campos M.S., Intestinal resections in rat. Influence of lipid absorption, J. Physiol. Biochem. 157 (1980) 187-190.

[7] Barrionuevo M., Campos M.S., GómezTravecedo M.T., Sanz Rus A., Compensatory capacity of remaining intestine in rats with intestinal resection: nutritive utilization 
of protein and fat, Ars Pharm. 26 (1985) 73-80.

[8] Barrionuevo M., Campos M.S., LópezAliaga I., Coves F., Lisbona F., Nutritive utilization of phosphorus in the rat: influence of intestinal resection and dietary medium chain triglycerides and vitamin $\mathrm{D}_{3}$, Int. J. Vitam. Nutr. Res. 59 (1989) 255-261.

[9] Barrionuevo M., Campos M.S., Urbano G., Varela G., Intestinal resections in rats. Influence on protein absorption, Rev. Esp. Fisiol. 36 (1980) 119-122.

[10] Barrionuevo M., López-Aliaga I., Alférez M.J.M., Mesa E., Nestares T., Campos M.S., Beneficial effect of goat milk on bioavailability of copper, zinc and selenium in rats, J. Physiol. Biochem. 59 (2003) 111-118.

[11] Becroft D.M.O., Holland J.T., Goat's milk and megaloblastic anaemia of infancy, N. Z. Med. J. 65 (1996) 303-307.

[12] Boulanger A., Grosclaude F., Mahé M.F., Polymorphism of caprine (Capra hircus) alpha-s-1 and alpha-s-2 caseins, Genet. Sel. Evol. 16 (1984) 157-175.

[13] Boza J., Sanz-Sampelayo M.R., Nutritional aspect of goat milk, Ann. Acad. Cienc. Vet. Andal. Orient. 10 (1997) 109-139.

[14] Campos M.S., Gómez-Travecedo M.T., Barrionuevo M., Mañas M., López-Aliaga I., Intestinal resection and calcium metabolism. Influence of 1,25 dihydroxy $\mathrm{D}_{3}$, Med. Sci. Res. 15 (1987) 419-420.

[15] Campos M.S., López-Aliaga I., Alférez M.J.M., Nestares T., Barrionuevo M., Effects of goats' or cows' milks on nutritive utilization of calcium and phosphorus in rats with intestinal resection, Br. J. Nutr. 90 (2003) 61-67.

[16] Campos M.S., López-Aliaga I., Barrionuevo M., Lisbona F., Coves F., Nutritive utilization of calcium in rats. Effects of dietary fat components and vitamin $\mathrm{D}_{3}$ on intestinal resected rats, J. Nutr. Sci. Vitaminol. 35 (1989) 511-521.

[17] Chandan R.C., Attaie R., Sahani K.M., Nutritional aspects of goat's milk and its products, in: Proceedings of 5th International Conference on Goats, New Delhi, India, vol. 2, part 2, 1992, pp. 399-420.

[18] Compston J.E., Merret A.L., Ledger J.E., Creamer B., Faecal tritium excretion after intravenous administration of $3 \mathrm{H}-25$-hydroxyvitamin D3 in control subjects and in patients with malabsorption, Gut 23 (1982) 310-315.
[19] Coves F., Lisbona F., Campos M.S., LópezAliaga I., Barrionuevo M., Influence of intestinal resection, type of dietary fat and time on the digestive and metabolic utilization of fat in rats, Biomed. Biochim. Acta 50 (1991) 285-292.

[20] Coves F., López-Aliaga I., Campos M.S., Lisbona F., Barrionuevo M., Influencia de la resección intestinal y de la calidad lipídica de la dieta sobre la utilización nutritiva de la grasa, Rev. Esp. Enf. Dig. 79 (1991) 9-14.

[21] Devine R.M., Nelly K.A., Surgical therapy of the short bowel syndrome, Gastroenterol. Clin. North Am. 18 (1989) 603-618.

[22] Erlinger S., Physiology of bile secretion and enterohepatic circulation, in: Jonson L.R. (Ed.), Physiology of the Gastrointestinal Tract, Raven, New York, USA, 1987, pp. 1557-1580.

[23] García Unciti M.S., Therapeutic utility of medium chain triglycerides (MCT). Cetogenic diets in infant epilepsy, Nutr. Clin. 16 (1996) 7-35.

[24] Gómez-Ayala A.E., Lisbona F., LópezAliaga I., Barrionuevo M., Pallarés I., Alférez M.J.M., Hartiti S., Campos M.S., Effects of intestinal resection, type of dietary fat and time on biliary lipid secretion in rats, Exp. Physiol. 79 (1994) 25-33.

[25] Grey V.L., Morin C.L., Evidence for a growth-stimulating fraction in the rat proximal intestine after small bowel resection, Gastroenterology 89 (1985) 1305-1312.

[26] Hachelaf W., Boulchrelda M., Benbouabdellah M., Coquin P., Desjeux J.F., Boudraa G., Touhami M., Digestibilité des graisses du lait de chèvre chez des enfants présentant une malnutrition d'origine digestive. Comparaison avec le lait de vache, Lait 73 (1993) 593-599.

[27] Haenlein G.F.W., Nutritional value of dairy products of ewe and goat milk, in: Production and utilization of ewe and goat milk, Proceedings of the IDF/Greek National Committee of IDF, CIRVAL Seminar, Crete, Greece, 19-21 October 1995, IDF Special Issue 9603, Int. Dairy Fed., Brussels, Belgium, 1996, pp. 159-178.

[28] Haenlein G.F.W., Past, present and future perspectives of small ruminant dairy research, J. Dairy Sci. 84 (2001) 2097-2115.

[29] Haenlein G.F.W., Goat milk in human nutrition, Small Rumin. Res. 51 (2004) 155-163. 
[30] Hartiti S., Barrionuevo M., López-Aliaga I., Lisbona F., Alférez M.J.M., Pallarés I., Gómez-Ayala A.E., Campos M.S., Effects of intestinal resection, cholecalciferol and ascorbic acid on iron metabolism in rats, Br. J. Nutr. 73 (1995) 871-880.

[31] Hartiti S., López-Aliaga I., Barrionuevo M., Lisbona F., Pallarés I., Alférez M.J.M., Gómez-Ayala A.E., Campos M.S., Zinc metabolism in rats: effects of intestinal resection, cholecalciferol and ascorbic acid, Nutr. Res. 14 (1994) 1523-1534.

[32] Hazel C., McCulloch C., Bjerknes M., Effects of $30 \%$ intestinal resection on whole population cell kinetics of mouse intestinal epithelium, Anat. Rec. 215 (1986) 35-41.

[33] Hylander E., Ladefoged K., Jarnum S., The importance of the colon in calcium absorption following small-intestinal resection, Scand. J. Gastroenterol. 15 (1980) 55-60.

[34] Jandal J.M., Comparative aspects of goat and sheep milk, Small Rumin. Res. 22 (1996) 177-185.

[35] Jauber O., Kalantzopoulos O., Quality of goat milk for cheese and other products, in: Proceedings of the 6th International Conference on Goats, vol. 1, International Academic Publishers, Beijing, China, 1996, pp. 274-284.

[36] Jenness R., Composition and characteristics of goat's milk, J. Dairy Sci. 63 (1990) 1605-1630.

[37] Kris-Etherton P.M., Yu S., Individual fatty acid effects on plasma lipids and lipoproteins: human studies, Am. J. Clin. Nutr. 65 (1997) 124-131.

[38] Kwan W.C., Quamne C.A., Freeman H.J., Sodium dependent D-glucose transport in brush-border membrane vesicles following massive distal small bowel resection in the rat, Gastroenterology 92 (1987) 1987-1993.

[39] Ladefoged K., Nicolaidou P., Jartum S., Calcium, phosphorus, magnesium, zinc, and nitrogen balance in patients with severe short bowel syndrome, Am. J. Clin. Nutr. 33 (1980) 2137-2144.

[40] Lisbona F., Alférez M.J.M., Barrionuevo M., López-Aliaga I., Pallarés I., Hartiti S., Campos M.S., Effect of type of dietary fat and vitamin $\mathrm{D}_{3}$ on magnesium absorption in rats with intestinal resection, Int. J. Vitam. Nutr. Res. 64 (1994) 135-143.

[41] Lisbona F., Campos M.S., Coves F., García J.A., Barrionuevo M., López-Aliaga I.,
Influence of ileal resection, type of diet and ursodeoxycholic acid on biliary secretion in rats, Exp. Physiol. 76 (1991) 567-572.

[42] López-Aliaga I., AlférezM.J.M., Barrionuevo M., Lisbona F., Campos M.S., Influence of goat and cow milk on the digestive and metabolic utilization of calcium and iron, J. Physiol. Biochem. 56 (2000) 201-208.

[43] López-Aliaga I., AlférezM.J.M., Barrionuevo M., Nestares T., Sanz-Sampelayo M.R., Campos M.S., Study on nutritive utilization of protein and magnesium in rats with resection of the distal small intestine. Beneficial effect of goat milk, J. Dairy Sci. 86 (2003) 29582966.

[44] López-Aliaga I., Alférez M.J.M., Lisbona F., Barrionuevo M., Hartiti S., Gómez-Ayala A.E., Campos M.S., Influence of vitamin $\mathrm{D}_{3}$ and type of dietary fat on phosphorus absorption in rats with intestinal resection, Nutr. Res. 14 (1994) 47-57.

[45] López-Aliaga I., Alférez M.J.M., Nestares T., Ros P.B., Barrionuevo M., Campos M.S., Goat milk feeding causes an increase in biliary secretion of cholesterol and a decrease in plasma cholesterol levels in rats, J. Dairy Sci. 88 (2005) 1024-1030.

[46] López-Aliaga I., Barrionuevo M., Campos M.S., Coves F., Lisbona F., Influence of intestinal resection and type of diet on digestive utilization and metabolism of magnesium in rats, Int. J. Vitam. Nutr. Res. 61 (1991) 61-66.

[47] López-Aliaga I., Campos M.S., Barrionuevo M., Coves F., Lisbona F., Influence of dietary fat on nutritive utilization of protein in intestinally resected rats, Nahrung 35 (1991) 285-292.

[48] López-Aliaga I., Campos M.S., Barrionuevo M., Lisbona F., Coves F., Influence of medium chain triglycerides and vitamin D on digestive and metabolic utilization of protein in rats with intestinal resection, Nahrung 34 (1990) 181-188.

[49] Matsuo T., Takeuchi H., Effects of structural medium- and long-chain triglycerides in diets with various levels of fat on body fat accumulation in rats, Br. J. Nutr. 91 (2004) 219-225.

[50] McCullough F.S.W., Nutritional interest of goat's milk. Present information and future prospects, in: International Symposium on the future of the sheep and goat dairy sectors, 2004, Zaragoza, Spain, CIHEAM-IAMZ, 2004 (CD-ROM). 
[51] Moneret-Vautrin A., Allergy to goat milk and sheep milk, in: International Symposium on the future of the sheep and goat dairy sectors, 2004, Zaragoza, Spain, CIHEAMIAMZ, 2004 (CD-ROM).

[52] Moreno R., Dairy as an ideal source of calcium/phosphorus in the diet, ANS Adv. Nurs. Sci. 2 (1995) 52-58.

[53] Murillo M.L., Campos M.S., Mataix J., Varela G., Influencia de las resecciones intestinales en la rata sobre algunos aspectos de las resecciones digestivas, Rev. Esp. Fisiol. 34 (1978) 365-370.

[54] Park Y.W., Relative buffering capacity of goat and cow milk, soy based infant formulas and commercial non prescription antiacid drugs, J. Dairy Sci. 74 (1991) 3326-3333.

[55] Park Y.W., Hypo-allergenic and therapeutic significance of goat milk, Small Rumin. Res. 14 (1994) 151-159.

[56] Park Y.W., Goat milk - chemistry and nutrition, in: Park Y.W., Haenlein G.F.W. (Eds.), Handbook of Milk of Non-bovine Mammals, Blackwell Publishing, Oxford, UK, 2006, pp. 34-58.

[57] Park Y.W., Haenlein G.F.W., Therapeutic and hypoallergenic values of goat milk and implication of food allergy, in: Park Y.W., Haenlein G.F.W. (Eds.), Handbook of Milk of Non-bovine Mammals, Blackwell Publishing, Oxford, UK, 2006, pp. 121-135.

[58] Park Y.W., Mahoney A.W., Hendricks D.G., Bioavailability of iron in goat milk compared with cow milk fed to anemic rats, J. Dairy Sci. 69 (1986) 2608-2615.
[59] Paul A.A., Southgate D.A., McCance and Widdowson's The Composition of Foods (Suppl. 1), 4th edn., Elsevier, Amsterdam, The Netherlands, 1978.

[60] Souci S.W., Fachmann W., Kraut H., Food composition and nutrition tables 1989/90, in: Garching B. (Ed.), Deutsche Forschungsanstalt für Lebensmittelchemie, 4th edn., München, Germany, 1989, pp. 13-14, 25-26.

[61] Trujillo A.J., Guamis B., Carretero C., The major protein of goat milk, Alimentaria 19 (1997) 19-28.

[62] Urban E., Campbell M.E., In vivo zinc transport by rat small intestine after extensive small bowel resection, Am. J. Physiol. 247 (1984) 88-94.

[63] Van Deest B.W., Fordtran J.S., Morawski S.G., Wilson J.D., Bile salt and micellar fat concentration in proximal small bowel contents of ileectomy patients, J. Clin. Invest. 47 (1968) 1314-1324.

[64] Velázquez O.C., Seto R.W., Rombeau J.L., The scientific rationale and clinical application of short-chain fatty acids and mediumchain triglycerides, Proc. Nutr. Soc. 55 (1996) 49-78.

[65] Visser G., Gray I., Williams M., Composition of New Zealand foods, Dairy Products, vol. 3 , DSIR, Palmerston North, New Zealand, 1991.

[66] Wilson H.D., Miller T., Ogesen B., Schedl H.P., Failla M.L., Loven D.P., Adaptation of the duodenum and ileum of the rat mid-gut resection: enzyme activity and trace metal status, Am. J. Clin. Nutr. 43 (1986) 185-193. 